\title{
Editors' Report for Volume 131 (2017)
}

Mailing dates for the four issues in volume 131 are as follows: 30 August 2017, 1 December 2017, 28 June 2018, and 11 April 2018. Summaries of the distribution of memberships in the Ottawa Field-Naturalists' Club, who all receive access to The Canadian Field-Naturalist, and subscribers to The Canadian Field-Naturalist for 2017 are provided in Table 1, along with comparison numbers for volume 130 . Institutional subscribers potentially represent many thousands of users. The number of articles published in volume 131 declined over the number published in volume 130 but the number of notes remained about the same (Table 2); birds and mammals were the main subject areas (Table 2). A new type of manuscript, thematic collections, began to be published in 2017; these are editor-selected compilations of previously-published contributions in both The Canadian Field-Naturalist and the regional Ottawa Field-Naturalists' Club publication, Trail \& Landscape, on a central theme. The number of book reviews and new titles published in volume 131 more than doubled and tripled, respectively, over the numbers in volume 130 (Table 3). The total number of pages published increased slightly for volume 131 over volume 130 (Table 4), with articles and notes contributing most to the page count although there was a decrease in the number of pages for articles as would be expected with six fewer articles being published (Table 2).

A number of new initiatives began with volume 131 in addition to the thematic collections. Beginning with issue 1, The Canadian Field-Naturalist had digital object identifiers (DOIs) automatically assigned to all published content via the Online Journal System. The DOI is a global system that provides a persistent link for digital content to a location on the internet. This system requires that all references cited within a manuscript also are identified with a DOI (providing they have one). Many older issues of The Canadian FieldNaturalist do not have DOIs but, to promote all previously published content in The Canadian Field-Naturalist available through the Biodiversity Heritage Library (BHL), the URL web address for each is added to the reference. All volumes of The Canadian Field-Natural-
TABLE 2. Number of research articles and notes published in The Canadian Field-Naturalist, volume 131 (volume 130), by major field of study. Two thematic collections, one on alvars in Canada and the other on documenting species new to Canada, also were published in volume 131 .

\begin{tabular}{lrrr}
\hline \hline Subject & Articles & Notes & \multicolumn{1}{c}{ Total } \\
\hline \hline Mammals & $3(9)$ & $8(10)$ & $11(19)$ \\
Birds & $10(4)$ & $6(5)$ & $16(9)$ \\
Amphibians and Reptiles & $3(4)$ & $2(0)$ & $5(4)$ \\
Fishes & $1(4)$ & $2(2)$ & $3(6)$ \\
Plants & $3(4)$ & $2(1)$ & $5(5)$ \\
Insects & $1(2)$ & $0(0)$ & $1(2)$ \\
Non-insect Invertebrates & $2(3)$ & $1(2)$ & $3(5)$ \\
Other & $1(0)$ & $0(0)$ & $1(0)$ \\
Total & $24(30)$ & $21(20)$ & $45(50)$ \\
\hline \hline
\end{tabular}

TABLE 3. Number of reviews and new titles published in the Book Review section of The Canadian Field-Naturalist, volume 131 (volume 130), by topic.

\begin{tabular}{lcc}
\hline \hline & Reviews & New Titles \\
\hline Zoology & $15(10)$ & $155(45)$ \\
Botany & $7(3)$ & $43(16)$ \\
Miscellaneous & $18(9)$ & $111(32)$ \\
Total & $40(22)$ & $309(93)$ \\
\hline \hline
\end{tabular}

ist more than six years old are freely available through the BHL. All URLs and DOIs also are made active in the online version of each article, by inserting an embedded hyperlink taking the online reader directly to the related publication or website.

The other new initiatives recognized historic field naturalists and awarded current publications. Beginning in issue 3 and as part of Canada's 150th birthday celebration in 2017, a section was added to the News and Comments to formally recognize Canada's greatest field naturalists. The first two Greatest Canadian FieldNaturalists were James Fletcher and John Macoun. A new award for the best paper published in the current volume of The Canadian Field-Naturalist, the James Fletcher Award, also was established in the same issue

TABLE 1. The 2017 (2016) circulation of The Canadian Field-Naturalist. Compiled by Eleanor Zurbrigg from the subscription list for 131(4).

\begin{tabular}{|c|c|c|c|c|}
\hline Subscriber Type & Canada & USA & Other & Total \\
\hline OFNC Members & $(58)$ & (3) & (1) & (62) \\
\hline \multicolumn{5}{|l|}{ Subscriptions: } \\
\hline Individual & $(21)$ & $7 \quad(6)$ & $0 \quad(1)$ & $33 \quad(28)$ \\
\hline Institutional & $73 \quad(84)$ & 106 (116) & 12 (13) & 191 (213) \\
\hline Total & $150(163)$ & $117 \quad(125)$ & 12 (15) & 279 (303) \\
\hline
\end{tabular}


TABLE 4. Number of pages per section published in The Canadian Field-Naturalist, volume 131 (130), by issue.

\begin{tabular}{|c|c|c|c|c|c|}
\hline & \multicolumn{4}{|c|}{ Issue } & \multirow[b]{2}{*}{ Total } \\
\hline & 1 & 2 & 3 & 4 & \\
\hline Editorials/Editors' Report & $0(0)$ & $0(3)$ & $2(0)$ & $1(0)$ & $3(3)$ \\
\hline Articles & $67(63)$ & $47(73)$ & $47(43)$ & $42(59)$ & $203(238)$ \\
\hline Notes & $7(18)$ & $17(14)$ & $30(14)$ & $27(21)$ & $81(67)$ \\
\hline Thematic Collections & $5(-)$ & $8(-)$ & $0(-)$ & $0(-)$ & $13(-)$ \\
\hline Tributes & $0(0)$ & $0(0)$ & $0(0)$ & $0(18)$ & $0(18)$ \\
\hline Book Reviews* & $14(8)$ & $15(4)$ & $15(9)$ & $13(11)$ & $57(32)$ \\
\hline News and Comment $\dagger$ & $2(1)$ & $1(2)$ & $6 \dagger(3)$ & $12(4)$ & $21(10)$ \\
\hline Reports: & $19(0)$ & $0(4)$ & $0(15)$ & $0(0)$ & $19(19)$ \\
\hline Erratum & $0(0)$ & $0(0)$ & $0(0)$ & $0(0)$ & $0(0)$ \\
\hline Index & $-(-)$ & $-(-)$ & $-(-)$ & $9(7)$ & $9(7)$ \\
\hline Total & $114(90)$ & $88(100)$ & $100(84)$ & $104(120)$ & $406(394)$ \\
\hline
\end{tabular}

*Includes reviews and new titles.

$\dagger$ Includes Greatest Canadian Field-naturalists and announcement of James Fletcher Award.

Includes Annual Business Meeting Minutes, Annual Committee Reports, Financial Statements, and Awards.

of volume 131; all these are available at https://doi. org/10.22621/cfn.v131i3.2071.

Fifty-seven manuscripts were submitted to The $\mathrm{Ca}$ nadian Field-Naturalist in 2017, 12 fewer than in 2016; all were submitted using the Online Journal System, some after an initial email submission. Ten of the 59 were for a Special Issue, "Studies on Canadian Amphibians and Reptiles in Honour of Dr. Francis Cook", scheduled for publication in 2018; one of those submitted in 2017 for the Special Issue was withdrawn because the author had insufficient time for revision and another did not make the revision deadline for the Special Issue. Only six of the 57 submitted manuscripts were not accepted for publication upon initial submission or review and one was withdrawn meaning $89.5 \%$ were accepted or undergoing revision. In 2016, 82.6\% of the 69 submissions were accepted for publication and either published or undergoing further revision and review. A total of 24 articles, 21 notes, and two thematic collections were published in 2017 (Table 2).

Dwayne Lepitzki was Editor-in-Chief for volume 131 while Amanda Martin, the Assistant Editor, edited content, proofread galleys, and sent and received author order and transfer of copyright forms. Sandra Garland and John Wilmshurst proof-read and copy-edited manuscripts. Wendy Cotie typeset galleys, provided corrections for page proofs, and created pdfs. Barry Cottam requested books for review, selected reviewers, edited submitted reviews, and prepared the new titles listings. Ken Young continued with the tasks of managing subscriptions, page charge invoices, and budget tracking although Eleanor Zurbrigg assumed the duties of managing subscriptions in the summer of 2017. William Halliday, Online Journal Manager and Webmaster, provided digital content to subscribers, posted tables of contents, abstracts, and pdfs on The Canadian FieldNaturalist website, and prepared the Index. Our Associate Editors managed manuscripts, provided reviews and recommendations, and guided authors through the revision process. The Publication Committee, chaired by Jeff Saarela and consisting of Annie Bélair, Dan Brunton, Carolyn Callaghan, Paul Catling, Barry Cottam, William Halliday, Diane Kitching, Dwayne Lepitzki, Amanda Martin, Karen McLachlan Hamilton, Frank Pope, David Seburn, and Eleanor Zurbrigg effectively guided the operation of the journal. We are indebted to our very dedicated team.

The following Associate Editors managed, assessed, and reviewed manuscripts published in volume 131: R. Brooks, University of Guelph, emeritus, Guelph ON (1 manuscript); P.M. Catling, Agriculture and Agri-Food Canada, retired, Ottawa ON (2); F. Chapleau, University of Ottawa, Ottawa ON (2); F.R. Cook, Canadian Museum of Nature, Emeritus, Ottawa ON (2); J. Foote, Algoma University, Sault Ste. Marie ON (8); G. Forbes, University of New Brunswick, Fredericton NB (3); A.J. Gaston, Environment Canada, Emeritus, Ottawa ON (2); W. Halliday, University of Victoria, Victoria, BC (2); T. Jung, Yukon Government, Whitehouse YT (5); D. Lepitzki, Banff AB (1); D.F. McAlpine, New Brunswick Museum, Saint John NB (7); J. McCraken, Bird Studies Canada, Port Rowan, ON (3); G. Mowat, government of British Columbia, Nelson BC (1); D.W. Nagorsen, Mammalia Biological Consulting, Victoria BC (1); M. Obbard, Ontario Ministry of Natural Resources and Forestry, Peterborough ON (1); J.M. Saarela, Canadian Museum of Nature, Ottawa ON (3); J. Skevington, Agriculture and Agri-Food Canada, Ottawa ON (1).

The following referees reviewed manuscripts published in volume 131 (number of manuscripts reviewed $>1$ in parentheses): Steve Ackers, Oregon State University; Kathryn Aitken, Yukon College (2); Noel Alfonso, Canadian Museum of Nature; Robert Alvo, Ottawa ON (2); Yves Aubrey, Environnement et Changement Climatique Canada; Shannon Barber-Meyer, US Geological Survey; Jason Beason, The Bird Conservancy; Rene 
Belland, University of Alberta; Sean Boyd, Environment and Climate Change Canada; Daniel Brunton, Ottawa ON (2); Rob Butler, Bird Studies Canada; Nick Cairns, Queens University; G. Campbell, University of Guelph; Andrew Campomizzi, Bird Ecology and Conservation Ontario; Adrian Carter, Agriculture Canada (retired); Paul Catling, Ottawa ON; Carina Cjerdrum, Environment and Climate Change Canada; Justin Congdon, University of Georgia (emeritus); Francis Cook, Canadian Museum of Nature (emeritus); Laura Corsitine, University of Ottawa; Shawn Crimmins, University of Wisconsin; Andrew Dennhardt, Michigan State University; Ken De Smet, Manitoba Conservation Data Centre; Jennifer Doubt, Canadian Museum of Nature (2); Martin Dube, Université de Moncton, Edmundston; Laura Feyrer, Dalhousie University; Mark Fisher, US Fish and Wildlife Service; Jennifer Foote, Algoma University (2); Graham Forbes, University of New Brunswick (3); Robert Forsyth, New Brunswick Museum and Royal BC Museum; Marcel Gahbauer, Migration Research Foundation; Craig George, North Slope Borough; Lynn Gillespie, Canadian Museum of Nature; Patrick Gregory, University of Victoria; Carolyn Gunn, US Forest Service; Allison Hahn, University of Wisconsin; Diana Hamilton, Mount Allison University; Kevin Hannah, Environment and Climate Change Canada; Judy Harpel, University of British Columbia Herbarium; Stephen Hecnar, Lakehead University; Grant Hilderbrand, US Geological Survey; Tara Imlay, Dalhousie University; Colin Jones, Ontario Ministry of Natural Resources and Forestry; Thomas Jung, Yukon Department of Environment and University of Alberta (2); Karl Larsen, Thompson Rivers University (2); Stephanie LaZerte, University of Northern BC; David Lee, Department of Wildlife and Environment, Nunavut Tunngavik Incorporated; Jose Lefebvre, Acadia; Marilyn Light, Ottawa ON; Stephen C. Lougheed, Queens University; Ian MacDonald, University of Calgary; Nancy Mahony, Environment and Climate Change Canada; Brian Mangan, King's College; Don McAlpine, New Brunswick Museum; Ashley McLaren, Ontario Ministry of Natural Resources and Forestry; Nicholas
Mandrak, University of Toronto - Scarborough; John Maunder, Pouch Cove NL; Jon McCracken, Bird Studies Canada; Paul Meek, NSW (Australia) Dept. Primary Industries \& Invasive Animal CRC; Greg Mitchell, Environment and Climate Change Canada; Patrick Nantel, Parks Canada; David Noakes, Oregon State University; Erica Nol, Trent University; Michael Oldham, Ontario Ministry of Natural Resources and Forestry; Kristiina Ovaska, Victoria BC; John Pastor, University of Minnesota; Cynthia Paszkowski, University of Alberta (2); Brent Patterson, Ontario Ministry of Natural Resources and Forestry; Thomas Pratt, Fisheries and Oceans Canada; Andrew Reid, Marine Animal Response Society; Greg Robertson, Environment and Climate Change Canada; Jeff Row, University of Waterloo; Jeffrey Rowell, Toronto ON; Charlotte Roy, Minnesota Department of Natural Resources; Jeff Saarela, Canadian Museum of Nature; Frederick Schueler, Bishop Mills ON (3); Fred Scott, Nova Scotia Museum; Robert Serrouya, Alberta Biodiversity Monitoring Institute; Jeffrey Skevington, Agriculture and Agri-Food Canada; James Stuart, New Mexico Department of Fish and Game; David Swanson, University of South Dakota; Anne Trainor, University of Cincinnati; Todd Underwood, Kutztown University; H. Vandermeulen, Fisheries and Oceans Canada; Jon Way, Eastern Coyote/Coywolf Research, Cape Cod MA; and Laura Weir, Saint Mary's University.

The journal was printed at Gilmore Printers, Ottawa. Thanks to Guylaine Duval of Gilmore Printers for overseeing production and printing. We are grateful to The Ottawa Field-Naturalists' Club President Diane Lepage and the club's Board of Directors for their support of the journal. We are also grateful to all of the individual subscribers and authors who support our team as we strive to provide a high-quality scientific journal on natural history, field biology, and ecology. Finally, we thank our families/partners for being patient and supportive throughout many long days, evenings, and weekends of working on the journal.

DWAYNE LEPITZKI, Editor-in-Chief Amanda Martin, Assistant Editor 